\title{
Sand invasion along the Portuguese coast forced by westerly shifts during cold climate events
}

\author{
Susana Costas ${ }^{\mathrm{a}, *}$, Sonia Jerez ${ }^{\mathrm{b}}$, Ricardo M. Trigo ${ }^{\mathrm{b}, \mathrm{c}}$, Ronald Goble ${ }^{\mathrm{d}}$, Luís Rebêlo ${ }^{\mathrm{a}}$ \\ a Unidade de Geologia Marinha, LNEG, 7586, Alfragide, 2610-999 Amadora, Portugal \\ b Instituto Dom Luiz, Universidade de Lisboa, 1749-016 Lisboa, Portugal \\ ${ }^{\mathrm{c}}$ Departamento de Engenharias, Universidade Lusófona, 1749-024 Lisboa, Portugal \\ ${ }^{\mathrm{d}}$ Department of Earth and Atmospheric Sciences, University of Nebraska, Lincoln, NE 68588-0340, USA
}

\section{A R T I C L E I N F O}

\section{Article history:}

Received 19 December 2011

Received in revised form

13 March 2012

Accepted 17 March 2012

Available online

\section{Keywords:}

Cliff-top dunes

OSL

GPR

Westerlies

Portugal

Paleoclimate

NAO

Storminess

\begin{abstract}
A B S T R A C T
Phases of higher aeolian activity are responsible for the formation and movement of large transgressive dunefields. Well-reported phases of aeolian activity in northwest Europe are coincident with global cooling events and were related to enhanced westerly winds and storminess. However, the extent to which these climatic episodes influenced dunefield dynamics in southwest Europe remains an open question. Ground penetrating radar (GPR) was used to image the stratigraphy of a cliff-top coastal transgressive dunefield in Portugal and reconstruct former windfield regimes. Using optically stimulated luminescence (OSL) five major phases of aeolian activity were dated at 12.6, 5.6, 1.2, 0.4 and $0.3 \mathrm{ka}$, and related to coastal instability and enhanced westerlies. These phases were later reconciled to favorable patterns of atmospheric circulation simulated by global and regional climate models at both synoptic and local scales, respectively. The results prove that major phases of aeolian activity in southwest Europe are associated with the onset of cold climate events of global distribution coinciding with aeolian accumulation in northwest Europe. This implies the dominance of zonal westerlies along the western coast of Europe from Denmark to Portugal during the onset of cold climate events. Model simulations suggest that the pattern of atmospheric circulation during periods of enhanced aeolian activity is compatible with prolonged negative phases of the North Atlantic Oscillation (NAO).
\end{abstract}

(C) 2012 Elsevier Ltd. All rights reserved.

\section{Introduction}

Environmental conditions during the end of the last glacial created the necessary conditions to trigger the formation of coversands in northwest and central Europe (Kasse, 2002; Renssen et al., 2007). The occurrence of coversands is patchy in Great Britain (Bateman, 1995) but on the continent the coversands form an extended latitudinal belt of continuous deposits including The Netherlands, Germany, Denmark, Poland and Russia (Zeeberg, 1998; Schirmer, 1999). However, significant aeolian activity in Europe was not restricted to the north of the continent. The accumulation of large dunefields was assigned to this time period in the south-west coast of France (Bertran et al., 2009), center of Spain (Bateman and Díez Herrero, 2001; García-Hidalgo et al., 2007), and some areas of the Portuguese (Ramos Pereira and Angelucci, 2004; Granja et al., 2008; Danielsen et al., 2011) and Atlantic Spanish coasts (Zazo et al., 2005). The synchronous character of aeolian accumulation along Europe suggests a common driving factor during the end of the

\footnotetext{
* Corresponding author.

E-mail address: susana.costas@lneg.pt (S. Costas).
}

last glacial. The climate has been repeatedly referred to as responsible for the formation of these aeolian deposits by changing the patterns of atmospheric circulation and thus sparseness of vegetation cover (Kasse, 2002). However, more information regarding the temporal and spatial resolution of the aeolian record is needed to better understand the palaeoclimatic implications of aeolian activity in the northeast Atlantic Basin. In this line, we will first investigate the circulation mode from the aeolian record of Caparica in Portugal by combining high-resolution Ground Penetrating Radar (GPR) images of the subsurface and Optically Stimulated Luminescence (OSL) ages. Then, making use of our current knowledge on atmospheric dynamics, proxy-based reconstructions will be reconciled with mesoscale and regional models of atmospheric circulation in an attempt to investigate the windfield regimes responsible for aeolian sand accumulation in the past.

\subsection{The Portuguese littoral belt}

The Portuguese coast extends for more than $900 \mathrm{~km}$, of which $60 \%$ are beaches and $36 \%$ contain cliffs without beaches (Andrade 